\title{
Well Practice And Accountability Of Zakat Management Through Culture Values Of Bugis Makassar Ethnic
}

\author{
Nun Fadilah Salam \\ Department of Accounting \\ Nobel Economics School of Indonesia, Makassar, Indonesia \\ nunfadilah@yahoo.co.id
}

\begin{abstract}
Accountability in Islamic principal is very important and necessary in managing the zakat funds. One of the accountability forms of zakat organizations is published financial statements. The zakat organizations obtain a mandate from the donors to manage and utilize zakat funds as well. The zakat organizations are responsible either to the donors and recipients or to Almighty God. The zakat organizations have a big role in social and economic life. Zakat as a form of social concern which can overcome poverty in a country and improve the quality of life of the recipients through programs of zakat utilization. Paying zakat is an obligation for Muslim. Indonesia is a country which has the majority of Muslim with great zakat potential but its realization is still low. This is due to the lack of public awareness in paying zakat and the lack of public trust against zakat organizations. To gain public trust in zakat organizations, good governance is needed, namely transparency and accountability. Lack of public trust is related to the zakat management which has many obstacles, such as the utilization of zakat funds is not well managed, the quality of human resources and integrity of zakat management is still low, lack of standardization of zakat management and internal control pretty weak. Hence, the purpose of this paper is to explore how to build a good accountability through culture values of Bugis Makassar ethnic group. Data collection method by performing the direct interview and observation to the respondent. The result is, that implementation of culture values Bugis Makassar ethnic group consist of "Siri or shame, lempu or honesty, getteng or consistent, acca or competence, asitinajang or properly, ada tongeng or the truth, and reso or effort" which the whole principal can build a good accountability in zakat management.
\end{abstract}

Keywords: Accountability, Culture Values, Zakat Management

\section{INTRODUCTION}

\subsection{Background of the Research}

There are many zakat organizations in Indonesia. Paying zakat is an obligation for Muslims. The zakat organizations have a big role in social and economic life. As a country which has the majority of Muslim, Indonesia has great zakat potential. Based on the research conducted by BAZNAS or Institution of National Zakat and IPB, the potential of zakat nationally in 2015 reached $R p 286$ trillion. However, the fact showed that the realization of zakat in Indonesia was still low. Baznas announced 
that zakat, infaq, and shadaqah funds who collected by government and private organizations nationally in 2015 were only Rp 3.7 trillion or 1.3 percent of its target (Maharani, 2016). This is due to the majority of Muslim still pay their zakat to the recipients directly and the lack of public trust to zakat organizations (Lestari et al., 2015).

Besides that, the knowledge and understanding of people about zakat are very minimum (Adnan, 2001). The lack of public trust is related to the zakat management which has many obstacles. The utilization of zakat funds is not well managed, the quality of human resources and integrity of zakat management are still low (Huda and Sawarjuwono, 2013). The lack of standardization of zakat management which can give a guarantee of good service quality to the stakeholders and society (IMZ and PEBS, 2009:58-67). Additionally, Nikmatuniayah (2014) proved that zakat organizations still had weakness in internal control.

To gain public trust against zakat organizations, accountability is very important and necessary in manage zakat funds. Accountability depicts a duty to execute and to calculate for the organization's accomplishment (Oakes and Young, 2008). Organizations attain a phase of accountability when managers accept to perform their assignments in the circle of belief and with high moral standards (Fowler, 2008). Costa, Ramus, and Andreaus (2011) explained that accountability comprises three factors: (a) financial sustainability, (b) social responsibility and (c) value creation. From that views, accountability is about values that must be implemented to reach organization purpose. This view is supported by Lannai and Prabowo (2016) who interpret accounting is not a discipline of knowledge that is value-free, but accounting contains values. Accounting values are related to the culture. Tricker (1987:8) describes accounting as a small part of a culture where accounting exists. Doupnik and Tsakumis (2004) stated that culture elements have the effect to the transformation of accounting and financial statements system in a country.

\subsection{Research Question}

How to build a good accountability through culture values of Bugis Makassar ethnic group?

\subsection{Research Purpose}

The purpose of this paper is to explore how to build a good accountability through culture values of Bugis Makassar ethnic group.

\section{LITERATURE REVIEW}

\subsection{Stakeholder Theory}

Clarkson (1995) defines stakeholders in the following way: "Stakeholders are persons or groups that have, or claim, ownership, rights, or interests in a corporation and its activities, past, present, or future. Such claimed rights or interests are the result of transactions with, or actions taken by, the corporation, and may be legal or moral, individual or collective. Stakeholders with similar interests, claims, or rights 
can be classified as belonging to the same group: employees, shareholders, customers and so on" (p.106). Stakeholder theory asserts a more exhaustive outlook of financial achievement, which can also be construed as a longer-term managerial orientation (Smith, 2014). Stakeholder ship consigns the assignment of the supervisor as observes of managers but notices the supervisor as assisting the managers whose success will assure stakeholder contentment. The presumption is that managers will attempt to fulfill the requirement of all stakeholders and conciliate the conflicts of interest that occur between the organization and the various stakeholder groups (Carroll and Buchholtz, 2009). The aim of the organization is to dedicate as a tool for harmonizing stakeholder interests (Freeman and Evan, 1990; Alam, 2006). If we associate with stakeholder theory, then zakat organizations should be accountable and provide benefits for stakeholders. Stakeholders are entitled to obtain information about the company's activities.

\subsection{Zakat}

According to the Law of The Republic of Indonesia Number 23 The year 2011 About Zakat Management (Undang-Undang Republik Indonesia Nomor 23 Tahun 2011 Tentang Pengelolaan Zakat), Zakat is a wealth that must be issued by a Muslim or business entity to be given to people who deserve it in accordance with Islamic Sharias. Zakat management is a planning, implementation, and coordinating activity in the collection, distribution, and utilization of zakat. Muslim or business entity who has obligation to pay zakat is called muzakki and people who deserve zakat is called mustahik. The management of zakat is based on:
a. Islamic law;
b. Trustworthy;
c. Benefit;
d. Justice;
e. Legal certainty;
f. Integrated; and
g. Accountability.

The management of zakat aims to:

a. Improve service effectiveness and efficiency in the management of zakat; and

b. Increase the benefits of zakat to achieve community welfare and resolve poverty.

Zakat includes zakat mal and zakat fitrah. Zakat mal comprises of:

a. Gold, silver, and other precious metals;

b. Money and other securities;

c. Commerce;

d. Agriculture, plantation, and forestry;

e. Livestock farming and fishery

f. Mining;

g. Industry;

h. Income and services; and

i. Rikaz. 


\subsection{Accountability}

In general, accountability indicates a connection between two sides in which one side (individual, group, company, government, organization, etc.) is directly or indirectly responsible for another side for something, whether it is an activity, development, and performance (Keans, 1994; Walker, 2002). Fishman (2007) describes accountability as the activities where funds collected and used for charity purpose and provide information about the utilization of its funds. Accountability also concerns about the transparency of management judgments (Baapogmah et al., 2015). Transparency and accountability cooperate to increase the consistency of management performance (Crofts and Bisman, 2010; Szper and Prakash, 2011).

The four elements of accountability (Ebrahim and Weisband, 2007):

1) Transparency, which includes amassing information and making it exist and Accessible for public investigation;

2) Answerability or Justification, which needs clear interpretation for activities and outcomes;

3) Compliance, through the observing and assessment of operations and results, integrated with transparency in informing those findings; and,

4) Enforcement or Sanctions for shortcomings in conformity, rationalization, or transparency.

Accountability for nonprofit organizations are expected to be responsible to many actors: upwards to the donors, downwards to recipients, and internally to nonprofit organizations and their missions (Edwards and Hulme, 1996a; Kearns, 1996; Lindenberg and Bryant, 2001; Najam, 1996).

\subsection{Culture}

According Hofstede's (1984) culture is "the collective programming of thinking which distinguishes the members of one group or society from another" (p. 82). Culture in its literal sense can be interpreted as the confidences, traditions, practices, and social attitude of a specific group. Culture's effect is usually proved in the following variables: language, religion, a way of dressing, educational systems, etc. Culture inclines to connect a group of people jointly very strongly and inculcates particular values very effectively (Francis and Okenwa, 2015).

\subsubsection{Hofstede's Cultural Dimensions}

The values of Hofstede's cultural dimensions, which consist of:

1. The Power Distance Index dimension, which is the basic assumption of how people difference is managed by different societies (Orr and Hauser, 2008). In a high power distance index culture, more interest will be located on status, level and centralized power (Samovar, Porter and McDaniel, 2009).

2. The Individualism dimension, which depicts the connection between individuals and their universal relationship in a particular society (McFarlin and Sweeney, 2006). In a high individualism culture, individuals inclined to protect themselves, contrary to the others (Orr and Hauser, 2008). 
3. The Masculinity dimension, which shows how the man and woman characteristics in a society divergent (Samovar et al., 2009; Orr and Hauser, 2008).

4. The Uncertainty Avoidance Index, which gives a clue about the society way receives uncertainty (Sternad, 2012; Avery, Baradwaj, and Singer, 2008).

\subsubsection{Gray's Accounting Value Dimensions}

Gray (1988) described four accounting value dimensions that can be used to explain a country's accounting (sub) culture:

1. Professionalism versus statutory control, delineates an option for individual professional consideration and professional self-regulation, as contradicted to prescriptive legal requirements and statutory control.

2. Uniformity versus flexibility depicts a selection for the enforcement of consistent accounting practices between companies as contradicted to flexibility in accordance with the conditions of individual companies.

3. Conservatism versus optimism represents an alternative to a conscientious approach to measurement that allows one to overcome with the uncertainty of future occurrences. It contradicts with a "more optimistic, laissez-faire, risk-taking approach".

4. Secrecy versus transparency, shows a choice for concealment, so that information about the business is revealed only to those most closely involved with management and financing. It contradicts with a more open, transparent, publicly responsible approach.

\section{METHODOLOGY}

\subsection{Location and Time Research}

This research was conducted at Zakat House (Rumah Zakat). The research duration is from April to July 2017.

\subsection{Data Collection Method}

Data collection method is used direct interview and observation to the respondent.

\subsection{Types and Sources of Data}

The type of data is used qualitative and quantitative data. The sources of data are from an interview with Makassar Branch Manager of Zakat House and observation.

\subsection{Data Analysis Method}

Data analysis method is used qualitative descriptive. Qualitative descriptive is to explain and explore the cultural values of Bugis Makassar ethnic in building good accountability at Zakat House. 


\section{RESEARCH FINDINGS AND DISCUSSION}

The Zakat House (Rumah Zakat) as one of zakat organizations in Indonesia that play a role in cope poverty. Accountability is important in the management of zakat funds. The management of zakat involves the collection, distribution, and utilization of zakat funds and internal control system. The result of an interview with Mr. Amir as Makassar Branch Manager of Zakat House:

1. Zakat Collection

"Zakat collection can be done in several ways, such as people can come to pay to Zakat House office, pick up zakat or staff of zakat house can come to donor house to take it, through sharing happiness and shopping while donating through shopping charity program in many partners of Zakat House. For the receipt of zakat is handled by the finance department."

2. Zakat Distribution

"The staffs of Zakat House conduct a survey by going to the recipient houses to know whether they are eligible to obtain zakat funds. For the distribution of zakat is handled by the program financial department."

3. Utilization of Zakat

"The mission of Zakat House is to facilitate the welfare of the community. The prosperous standard is to transform the recipients into donors. There are several programs of community empowerment in Zakat House:

a. Education sector (Champion Smile)

b. Economic sector (Independent Smile)

c. Health sector (Healthy Smile)

d. Environmental sector (Everlasting Smile)."

4. Internal control system

"The internal control system of Zakat House consists of:

1. Internal audit

a. In each part, there is a fund authorization.

b. To pick up donations, zakat received today must be inputted the data no later than tomorrow.

c. To know whether zakat funds have been given to the recipients, then program audit part will check into each beneficiary's house to ensure that they have received the zakat according to its value.

\section{External audit."}

Good accountability in an organization can be realized by application the culture values. The culture of Bugis Makassar as one of the local culture in Indonesia has influenced accounting practices, specific in this case is accountability. The culture values of Bugis Makassar ethnic comprise of Siri' (shame or self-regard), lamps (honesty), getteng (consistent), acca (smart, intelligent or competence), asitinajang (properly), ada tongeng (truth) and reso (effort in achieving goals). The result of an interview with Mr. Amir about the cultural values of Bugis Makassar ethnic that implemented in Zakat House: 
1. Siri'

"Siri' is actually an internal strengthening of the culture of Amanah. Every employee should feel ashamed when doing mistakes and cheating. Siri' is a strong point of self."

2. Lempu

"Honesty begins with shame. When someone lies, then he will not be trusted. The honest attitude should be applied in the management of Zakat House."

3. Getteng

"As a religious person, when given the rules, it must be obeyed and consistent."

4. Acca

"In Zakat House, every employee has only basic competence. Now people work not in accordance with their educational background. Our work in Zakat House is able to deliver in heaven or hell."

5. Asitinajang

"Asitinajang is obedient to the rules and discipline. In Zakat House, we come to the office at 8 am and back to the home at $5 \mathrm{pm}$. If we come late, we will be fined. If you want to leave office when it still working hours, you have to ask permission. This is applied to make employees discipline."

6. Ada tongeng

"The data presented must be in accordance with the facts and conditions in the field."

7. Reso

"Reso is a success in line with effort, so zakat must be socialized and promoted to society."

In Zakat House, the cultural values of Bugis Makassar ethnic are known as institution values and key behaviors that are part of the whole of cultural transformation.

Table 1. Institution Values and Key Behaviors of Zakat House

\begin{tabular}{|c|c|c|}
\hline & Description & Key Behaviors \\
\hline Synergy & $\begin{array}{l}\text { Always ready to work together } \\
\text { And collaborate with each } \\
\text { Component to produce optimal } \\
\text { The result, effective and efficient. }\end{array}$ & $\begin{array}{l}\text { 1. Nice person } \\
\text { 2. Results-oriented } \\
\text { 3. Sportsmanship }\end{array}$ \\
\hline Inspirational & $\begin{array}{l}\text { The spirit to produce creative } \\
\text { Work includes values, ideas } \\
\text { And products to give influence } \\
\text { To the environment. }\end{array}$ & $\begin{array}{l}\text { 1. Ability to build } \\
\text { 2. Ability to influence } \\
\text { 3. Creative }\end{array}$ \\
\hline
\end{tabular}




\begin{tabular}{|c|ll}
\hline \multirow{2}{*}{ Amanah } & $\begin{array}{l}\text { Always enthusiastic to give the } \\
\text { Highest dedication to Allah SWT. } \\
\text { Willing to sacrifice and be faithful } \\
\text { To the vision and mission. }\end{array}$ & $\begin{array}{l}\text { 1. Responsibility } \\
\text { 2. Dedicated } \\
\text { 3. Honest }\end{array}$ \\
\hline \multirow{2}{*}{ Professional } & $\begin{array}{l}\text { Attitudes are based on a good } \\
\text { Understanding of the rules and } \\
\text { Realized in the form of excellent } \\
\text { Performance. }\end{array}$ & $\begin{array}{l}\text { 1. Obey the rules } \\
\text { 2. Discipline } \\
\text { 3. Productivity-oriented }\end{array}$ \\
\hline
\end{tabular}

In connection with cultural values of Bugis Makassar ethnic and accountability, Mr. Amir stated: "By applying the culture values of Bugis Makassar, it will create accountability."

Based on the results of an interview can be seen that the accountability of zakat management involves the collection, distribution, utilization of zakat and internal control system. The zakat organizations must be accountable to stakeholders and provide information about their activities including financial statements. To create good accountability in the management of zakat, the implementation of cultural values of Bugis Makassar ethnic is very important.

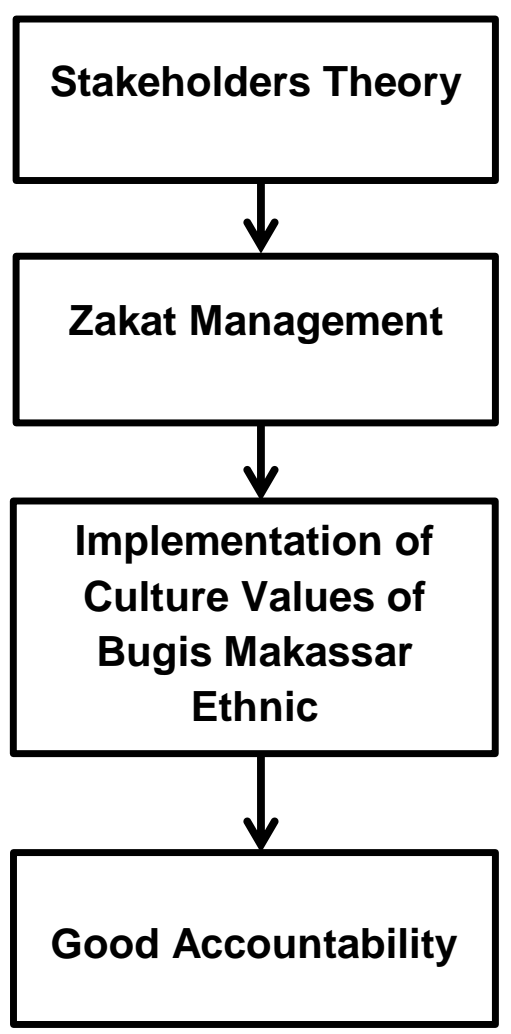

Figure 1. The Conceptual Framework 
Table 2. Financial Statements of Rumah Zakat Foundation

STATEMENTS OF FINANCIAL POSITIONS

As of December 31, 2016

(Expressed in Rupiah, unless otherwise stated)

\section{ASSETS \\ Current Assets}

Cash and cash equivalents

Time deposits

Receivables

Inventories

Advances

Prepaid expenses

Investments

Total Current Assets

16.843.594.686

750.000 .000

305.284 .303

125.257 .420

1.379.703.474

4.505 .000 .000

23.908.839.883

Non-Current Assets

Restricted cash

2.500.000.000

Fixed assets-net of Accumulated depreciation 2016: Rp 5.640.056.323

Management assets

Guarantees

Total Non-Current Assets

8.265.968.885

TOTAL ASSETS

32.174.808.768

LIABILITIES AND FUNDS

Current Liabilities

Taxes payable

Accrued expenses

33.470 .252

Other payables

1.654 .101 .631

675.643 .231

2.363.215.114

Total Current Liabilities

$\begin{array}{r}2.293 .703 .000 \\ \hline 2.293 .703 .000 \\ \hline\end{array}$

$\frac{2.293 .703 .000}{2.293 .703 .000}$

Total Non-Current Liabilities

Funds Balance

Zakat funds

5.397 .241 .776

Infaq/sedekah unrestricted funds

1.290 .960 .381

Infaq/sedekah restricted funds

15.050 .721 .037

Amil funds

Charity funds

5.520 .265 .186

258.702 .274

Total Funds

27.517.890.654

TOTAL LIABILITIES AND FUNDS

32.174.808.768 
STATEMENTS OF CHANGES IN FUNDS

For the year ended December 31, 2016

(Expressed in Rupiah, unless otherwise stated)

\section{ZAKAT FUNDS}

\section{Receipts}

Zakat professions

86.377.369.249

Zakat savings

17.247.988.191

Zakat trades

3.439 .451 .230

Zakat fitrah

812.622 .850

Zakat of gold and silvers

550.584 .506

Zakat shares and investments

403.860.597

Zakat gifts

Zakat agricultures

Zakat farm

187.968 .073

108.422 .943

Non cash zakat

7.555 .000

53.522 .900

Placement revenues

149.535 .792

Total Receipts

109.338.881.331

\section{Distributions}

\author{
Fakir \\ Fisabilillah \\ Amil \\ Ghorimin \\ Ibnu sabil \\ Muallaf \\ Non cash zakat \\ Allocation of assets under \\ Management utilization of zakat \\ Total Distributions
}

Net increase (decrease)

Balance at beginning of year

Balance at the End of the Year
68.285.161.639

30.942 .897 .908

13.642.005.955

285.575 .053

224.057.372

66.154 .517

58.714 .900

94.938 .618

113.599.505.962

(4.260.624.631)

9.657 .866 .407

5.397.241.776 


\section{INFAQ/SEDEKAH FUNDS}

\section{Unrestricted Funds}

\section{Receipts}

Receipts of infaq unrestricted funds

54.540 .985 .527

Non cash of infaq unrestricted funds

997.167 .500

Receipts of management revenues

74.731 .003

\section{Total Receipts}

Allocation from (for) amil funds

Allocations from (for) restricted infaq funds

Allocations between funds

Total Receipts After

The Allocation of Funds

$\mathbf{5 5 . 6 1 2 . 8 8 4 . 0 3 0}$

(10.248.169.979)

(21.324.680.492)

5.715.737.166

29.755.770.725

\section{Distributions}

Distributions of infaq unrestricted funds

28.778.644.091

119.542 .500

Non cash of infaq unrestricted funds

19.136.112

Management utilization of infaq

Total Distributions

28.917.322.703

Net increase (decrease)

838.448 .022

Balance at beginning of year

452.512 .359

Balance at the End of the Year

1.290 .960 .381

\section{INFAQ/SEDEKAH FUNDS}

\section{Restricted Funds}

\section{Receipts}

Receipt of educational funds

34.170.019.037

Receipt of incidental funds

Receipt of health care funds

11.975.644.669

4.855.279.793

Receipt of Ramadan funds

1.847 .768 .590

Receipt of economic empowerment funds

1.575 .333 .738

Receipt of environmental funds

1.399.360.862

Receipt of integrated community

Development (ICD)

911.663 .347

421.623 .001

644.624 .307

540.589 .486

Receipt of youth care funds

Receipt of qurban funds

Non cash of infaq restricted funds

Receipts of management revenues

67.065 .000

79.938 .952

Total Receipts

58.488.910.782 
Allocations from unrestricted funds

21.324.680.492

Allocation for amil funds

$(10.697 .395 .108)$

Allocation between funds

(4.188.132.855)

Reclass correction funds

Total Receipts after The Allocation of Funds

64.928.063.311

\section{Distributions}

Distribution for educational program

Distribution for health care

29.182.065.919

Distribution for integrated community

Development

7.407.981.026

Distribution for incidental

6.577 .531 .992

4.501.211.735

National distribution funds

2.802.433.595

Distribution for economic empowerment

2.752.651.818

Distribution for Ramadan

1.654 .084 .625

Distribution for environmental

1.459 .427 .648

Distribution for youth care

Distribution for fidyah

1.043.340.407

13.250 .000

1.730 .800

Distribution for SIGI

54.352 .000

Non cash of infaq restricted funds

Allocation of assets under

Management utilization of infaq

41.216 .028

Total Distributions

57.491.277.593

997.633.189

Transfer between funds

Net increase (decrease)

Balance at beginning of year

7.436.785.718

7.613.935.319

Balance at the End of the Year

15.050.721.037

\section{AMIL FUNDS}

\section{Receipt}

Amil part of restricted funds

Amil part of unrestricted funds

10.697.395.108

Receipts of donations

10.248.169.979

902.795 .014

Revenue sharing from Bank

111.990 .211

Others

Non cash receipts

Total receipt

73.343 .500

Allocation between funds

22.033.693.812

$(1.527 .604 .311)$

Other comprehensive income (expense)

(11.601.000)

Total Receipts after the Allocation of Funds

20.494.488.501 


\section{Disbursements}

Operating expenses

10.920.759.037

Salary and wages

4.820 .051 .132

Advertising and marketing expenses

4.077.643.985

Rent expenses

1.670 .538 .583

785.427 .334

Training and development expenses

290.697 .048

Depreciation of fixed assets

522.866 .657

Employee benefit

137.546 .064

Interest expenses

1.045 .978

Loss from foreign exchange

28.037.338

Insurance expenses

81.628 .801

Total Disbursements

23.336.241.957

Net increase (decrease)

(2.841.753.456)

Balance at beginning of year

8.362.018.642

Balance at the End of the Year

5.520.265.186

\section{CHARITY FUNDS}

\section{Receipt}

Interest

40.941 .833

Others

445.797 .019

486.738.852

\section{Disbursements}

Public facilities maintenance

Total Disbursements

239.283.016

239.283.016

Surplus (Deficit)

247.455 .836

Balance at beginning of year

11.246 .438

Balance at the End of the Year

258.702.274 


\section{STATEMENTS OF CHANGES IN ASSET MANAGEMENT \\ For the year ended December 31, 2016 \\ (Expressed in Rupiah, unless otherwise stated)}

\begin{tabular}{|c|c|c|c|c|c|}
\hline Description & $\begin{array}{l}\text { Beginning } \\
\text { Balance }\end{array}$ & Additional D & Iuction & $\begin{array}{l}\text { Accumulated } \\
\text { Depreciation }\end{array}$ & $\begin{array}{l}\text { Ending } \\
\text { Balance }\end{array}$ \\
\hline \multicolumn{6}{|l|}{ Infaq Funds } \\
\hline PAUD Juara & 585.833 .333 & - & - & 37.000 .000 & 548.833 .333 \\
\hline Laptop & 1.002 .500 & 7.500 .000 & - & 1.210 .833 & 7.291 .667 \\
\hline Land & 255.000 .000 & - & - & - & 255.000 .000 \\
\hline Motorcycle & 9.200 .000 & - & - & - & 9.200 .000 \\
\hline Printer & 735.750 & 2.500 .000 & - & 805.194 & 2.430 .556 \\
\hline \multicolumn{6}{|c|}{ Infaq Unrestricted } \\
\hline \multicolumn{6}{|l|}{ Funds } \\
\hline Laptop & - & 9.500 .000 & - & 1.708 .333 & 7.791 .667 \\
\hline $\mathrm{CPU}$ & - & 60.000 .000 & - & 5.738 .889 & 54.261 .111 \\
\hline House & - & 500.000 .000 & - & 12.500 .000 & 487.500 .000 \\
\hline Land & - & 360.000 .000 & - & - & 360.000 .000 \\
\hline$A C$ & - & 8.050 .000 & - & 2.345 .833 & 5.704 .167 \\
\hline Computer & - & 15.212 .500 & - & 2.692 .014 & 12.520 .486 \\
\hline \multicolumn{6}{|l|}{ Zakat Funds } \\
\hline \multicolumn{6}{|l|}{ SMP Juara } \\
\hline Bandung & 1.396 .634 .560 & - & - & 87.289 .6601 & 1.309 .344 .900 \\
\hline House & 21.666 .667 & - & - & 4.000 .000 & 17.666 .667 \\
\hline Land & 1.150 .000 .000 & - & - & - & 1.150 .000 .000 \\
\hline Total & 3.420 .072 .810 & 962.762 .500 & - & 155.290 .7564 & 4.227 .544 .554 \\
\hline
\end{tabular}




\section{Discussion}

The findings of this research depict that the management of zakat comprises of:

1. Zakat collection and for its receipt is handled by the finance department.

2. Zakat distribution where the staffs will visit the recipient houses to find out whether they deserve zakat funds and for the distribution of zakat is handled by the program financial department.

3. The utilization of zakat is done through the community empowerment programs that is the champion smile for education, independent smile for economic, healthy smile for health and everlasting smile for environmental.

4. An internal control system that includes internal audit and external audit.

To create good accountability in the management of zakat, then it is necessary for implementing the culture values that transformed into the institution values of zakat organizations. The culture values of Bugis Makassar that are implemented in the management of zakat are:

1. Siri' (shame or self-regard)

Every employee must have a shame so that they will attempt not to make mistakes.

2. Lempu (honesty)

The manager and staffs of zakat organizations must have an honest attitude.

3. Getteng (consistent)

Every employee must obey the rules and consistent.

4. Acca (smart, intelligent or competence)

Every employee must have competence in reaching goals of zakat organizations.

5. Asitinajang (properly)

When given the task, it must be done professionally and provide the best performance.

6. Ada tongeng (truth)

The data and information that presented must be in accordance with the facts.

7. Reso (effort)

To achieve the vision and mission of zakat organizations, it requires effort and sacrifice.

The culture values of Bugis Makassar are transformed into the institution values where siri' and lempu culture are known as Amanah, getteng is professional, acca is inspirational, asitinajang is inspirational and professional, ada tongeng is Amanah and reso is synergy. 


\section{CONCLUSION AND IMPLICATIONS}

\section{Conclusion}

The implementation of the cultural values of Bugis Makassar ethnic consisting of siri', lempu, getteng, acca, asitinajang, ada tongeng and reso can build good accountability in zakat management, with siri' culture as a strong point of self. If good accountability is realized, it will increase the public trust to zakat organizations so that many people will pay their zakat through zakat organizations. In manage zakat funds, zakat organizations are responsible not only to the donors, recipients, and communities but also to God.

\section{Implications}

The implementation and strengthening of cultural values of Bugis Makassar through institution values is necessary to be done by zakat organizations in achieving their goals to facilitate the prosperity of the community. 


\section{REFERENCES}

Adnan, M. A. 2001. Sebuah Kata Pengantar dalam Buku Akuntansi dan Manajemen Keuangan Organisasi Pengelola Zakat, Jakarta : Institut Manajemen Zakat (IMZ).

Alam, M. 2006. "Stakeholder Theory", In Z. Hoque (Ed.), Methodological Issues in Accounting Research: Theories and Methods (pp. 207-222), London: Spiramus Press Ltd.

Avery, A. E., B. G. Baradwaj, and D. D. Singer. 2008. "An Examination of Hofstede's Cultural Factors in Explanation of Differences in Citibank International Retail Banking WebSites", Journal of Business and Economic Studies, vol.14, no. 2, pp. 73-90.

Baapogmah, F. A., Mayer, R. W., Chien W. W. and Afolabi, A. 2015. "Control Mechanisms And Accountability Challenges In Nonprofit Organizations", Global Journal of Business Research, vol. 9, no. 1, pp. 27-38.

Carroll, A. B., and Buchholtz, A. K. 2009. Business and Society: Ethics and Stakeholder Management (7th Ed), Mason, USA: South-Western Cengage Learning.

Clarkson, M.E. 1995. "A stakeholder framework for analyzing and evaluating corporate social performance", Academy of Management Review, vol. 20, no. 1, pp. 92-117.

Costa, E., Ramus, T. and Andreaus, M. 2011. "Accountability As A Managerial Tool In Non-Profit Organizations: Evidence From Italian CSVs", Voluntas, vol. 22, pp. 470-493.

Crofts, K. and Bisman, J. 2010. "Interrogating Accountability", Qualitative Research in Accounting and Management, vol. 7, pp. 180-207.

Doupnik, T. S., and Tsakumis, G. T. 2004. "A Critical Review of the Tests of Gray's Theory of Cultural Relevance and Suggestions for Future Research", Journal of Accounting Literature, vol. 23, pp. 1-30.

Ebrahim, A. and E. Weisband (eds). 2007. Global Accountabilities: Participation, Pluralism and Public Ethics, Cambridge: Cambridge University Press.

Edwards, M. and D. Hulme (eds). 1996a. Beyond the Magic Bullet: NGO Performance and Accountability in the Post-Cold War World, West Hartford, Connecticut: Kumarian Press.

Fishman, J. J. 2007. The Faithless Fiduciary and the Quest for Charitable Accountability 1200-2005, Durham, North Carolina: Carolina Academic Press.

Fowler, D. 2008. "Student Midwives and Accountability: Are Mentors Good Role Models?", British Journal of Midwifery, vol. 16, no. 2, pp. 100-104. 
Francis, E. C., and Okenwa, C. Y. O. 2015. "The Influence of Cultural Values on Accounting Practice in Nigeria", Developing Country Studies, vol. 5, no. 3, pp. 110-121.

Freeman, R. E., and Evan, W. M. 1990. "Corporate Governance: A Stakeholder Interpretation", The Journal of Behavioral Economics, vol. 19, no. 4, pp. 337359.

Gray, S.J. 1988. "Towards A Theory of Cultural Influence on the Development of Accounting Systems Internationally", Abacus, vol. 24, pp. 1-15.

Hofstede, G. 1984. "Cultural Dimensions In Management and Planning", Asia Pacific Journal of Management, vol. 1, no. 2, pp. 81-99.

Huda, N. dan Sawarjuwono, T. 2013. Akuntabilitas Pengelolaan Zakat Melalui Pendekatan Modifikasi Action Research, Jurnal Akuntansi Multiparadigma, Vol. 4, No. 3, HIm 376-388.

Indonesia Magnificence of Zakat (IMZ) dan PEBS. 2009. Indonesia Zakat and Development Report 2009 : Zakat dan Era Pembangunan : Era Baru Zakat Menuju Kesejahteraan Ummat, Indonesia Zakat dan Development Report, Jakarta.

Keans, K. P. 1994. "The Strategic Management of Accountability in Non-Profit Organizations: An Analytical FrameWork", Public Administration Review, vol. 54, no. 2, pp. 185-192.

Kearns, K. P. 1996. Managing for Accountability: Preserving the Public Trust in Nonprofit Organizations, San Francisco: Jossey-Bass.

Lannai, D. and Prabowo, M. A. 2016. "Strengthening the Auditor Ethics with Bugis Culture Value in Phenomenology Perspective at Makassar-Indonesia", Australian Journal of Basic and Applied Sciences, vol. 10, no. 16, pp. 263274.

Lestari, P., Pratiwi, U. dan Ulfah, P. 2015. Identifikasi Faktor Organisasional dalam Pengembangan "E-Governanace" pada Organisasi Pengelola Zakat. MIMBAR, vol. 31, no. 1, pp. 221-228.

Lindenberg, M. and C. Bryant. 2001. Going Global: Transforming Relief and Development NGOs, Bloomfield, CT: Kumarian Press.

Maharani, E. 2016. Realisasi Zakat di Indonesia Hanya 1,3 Persen dari Potensi, http://www. republika.co.id/berita/ramadhan /kabar-ramadhan /16/06 /30 lo9kpn5335 - realisasi -zakat -di- indonesia- hanya -13-persen -dari -potensi (accessed on July 20, 2017 at 5 pm).

McFarlin, D. B., and P. D. Sweeney. 2006. International Management: Strategic Opportunities and Cultural Challenges, 3rd ed, New York: Houghton Mifflin. 
Najam, A. 1996. "NGO Accountability : A Conceptual Framework", Development Policy Review 14, 339-53.

Nikmatuniayah, 2014. Komparasi Sistem Pengendalian Internal Pengelolaan Lembaga Amil Zakat, Jurnal Akuntansi Multiparadigma (JAMAL), vol. 5, no. 3, Desember, pp. 498-510.

Oakes, L. S., and Young, J. J. 2008. "Accountability re-examined: Evidence from Hull House", Accounting, Auditing, and Accountability Journal, vol. 21, pp. 765-790.

Orr, L. M., and W. J. Hauser. 2008. "A Re-inquiry of Hofstede's Cultural Dimensions: A Call for 21st Century Cross-Cultural Research", The Marketing Management Journal, vol. 18, no. 2, pp. 1-19.

Samovar, L. A., R. E. Porter, and E. R. McDaniel. 2009. Communication Between Cultures, 7th ed, Boston, ma: Wadsworth.

Smith, S. S. 2014. "Integrated Reporting, Corporate Governance, and the Future of the Accounting Function", International Journal of Business and Social Science, vol. 5, no. 10, pp. 58-63.

Sternad, D. 2012. "Adaptive Strategies in Response to the Economic Growth Crisis: A Cross-Cultural Study in Austria and Slovenia", Managing Global Transitions, vol. 10, no. 3, pp. 257-82.

Szper, R. and Prakash, A. 2011. "Charity Watchdogs and the Limits of InformationBased Regulation”, Voluntas, vol. 22, pp. 112-141.

Tricker, A. 1987. The Infiltration Cylinder: Some Comments On Its Use, Elsevier Scientific Publishing, Amsterdam.

Undang-Undang Republik Indonesia Nomor 23 Tahun 2011 Tentang Pengelolaan Zakat.

Walker, P. 2002. "Understanding Accountability: Theoretical Models and Their Implications for Social Service Organizations", Social Policy and Administration, vol. 36, no. 1, pp. 62-75. 